\title{
Decolonisation of higher education: Dismantling epistemic violence and Eurocentrism in South Africa
}

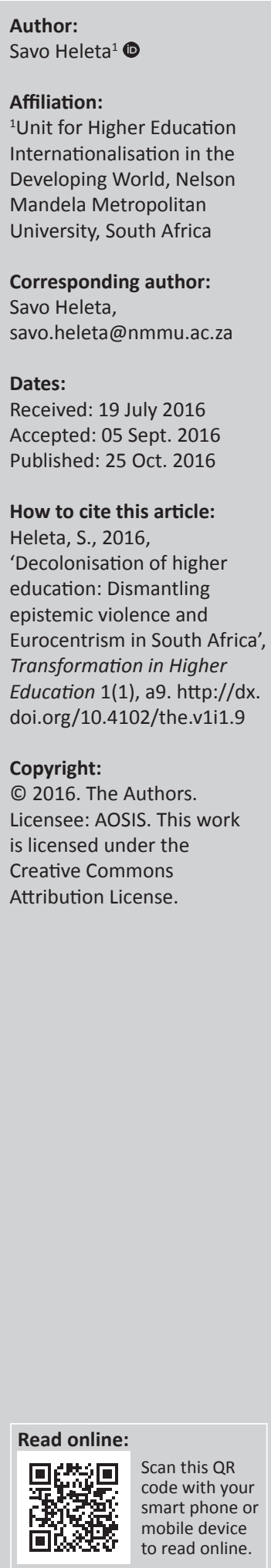

Since the end of the oppressive and racist apartheid system in 1994, epistemologies and knowledge systems at most South African universities have not considerably changed; they remain rooted in colonial, apartheid and Western worldviews and epistemological traditions. The curriculum remains largely Eurocentric and continues to reinforce white and Western dominance and privilege. This article traces the roots of Eurocentrism and epistemic violence at universities. The author argues that South Africa must tackle and dismantle the epistemic violence and hegemony of Eurocentrism, completely rethink, reframe and reconstruct the curriculum and place South Africa, Southern Africa and Africa at the centre of teaching, learning and research. However, this will not be easy as opposition to change is entrenched in the university structures. The movement to radically transform and decolonise higher education must find ways to hold institutions accountable and maintain the non-violent and intellectual struggle until epistemic violence and Eurocentrism are dismantled.

\section{Introduction}

South African students and a small number of progressive academics began a campaign in 2015 to decolonise the curriculum at universities 'by ending the domination of Western epistemological traditions, histories and figures' (Molefe 2016:32). In particular, the students have called for the end of domination by 'white, male, Western, capitalist, heterosexual, European worldviews' in higher education and incorporation of other South African, African and global 'perspectives, experiences [and] epistemologies' as the central tenets of the curriculum, teaching, learning and research in the country (Shay 2016).

Students have questioned not only the lack of transformation in the higher education sector but also the settlement that ended apartheid more than two decades ago. Jacobs (2016) calls the settlement between the apartheid regime and the African National Congress 'the series of political, social and economic deals in which the racial inequalities of apartheid and wealth disparities largely remain intact and which benefits whites in general'. While the 1994 settlement has brought political change, it has not done much to tackle poverty and inequality, which is an all-toocommon lived experience of the black majority. Thus, the student activists speak about disrupting 'whiteness' in society, the economy and at universities. The whiteness they are trying to disrupt has been imposed since colonial times as a 'symbol of purity' and has defined 'what it means to be civilised, modern and human' (Sardar 2008:xiii). This whiteness is still engaged in daily open and/or subtle racism and marginalisation of black people.

Nwadeyi (2016) argues that 'colonialism, apartheid and other vehicles for entrenching white supremacy did not only affect political rights or economic freedoms'. They have affected every aspect of life and their effects and legacies are still entrenched in South Africa. Writing about Frantz Fanon's works in a foreword to the 2008 edition of Black Skins, White Masks, Sardar (2008:xviii) admits that much has changed in the world since Fanon wrote this and other books. However, 'the underlying structures of oppression and injustice remain the same'. This is particularly true in post-apartheid South Africa. Whereas political freedom was achieved in 1994, many structural imbalances, inequalities and injustices remain stumbling blocks for the emancipation of black South Africans. Institutions of higher learning are one of these stumbling blocks. As Sardar (2008) points out:

Note: Dr Savo Heleta works at Nelson Mandela Metropolitan University in Port Elizabeth, South Africa. He writes this article in his personal capacity. The views expressed are his own and do not necessarily represent the views of his employer. 
If Western civilisation and culture are responsible for colonial racism, and Europe itself has a racist structure, then we should not be too surprised to find this racism reflected in the discourses of knowledge that emanate from this civilisation and that they work to ensure that structural dominance is maintained. (p. $x v$ )

The universities have done very little since 1994 to open up 'to different bodies and traditions of knowledge and knowledge-making in new and exploratory ways'. While all universities have had new policies and frameworks that speak about equality, equity, transformation and change, institutional cultures and epistemological traditions have not considerably changed. Policies might be there but the willingness to implement them is lacking (Department of Education $^{1}$ 2008:41). The South African higher education system 'remains a colonial outpost' up to this day, reproducing 'hegemonic identities instead of eliminating hegemony' (McKaiser 2016). Mbembe (2016:32) argues that 'there is something profoundly wrong when ... syllabuses designed to meet the needs of colonialism and apartheid should continue well into the liberation era'. This is why it is of paramount importance to bring about fundamental epistemological change at institutions of higher learning.

This article traces the roots of epistemic violence at South African universities. The focus is on the curriculum, which remains largely Eurocentric and continues to reinforce white and Western dominance and privilege while at the same time being full of stereotypes, prejudices and patronising views about Africa and its people. The article stresses that South Africa must completely rethink, reframe and reconstruct the Eurocentric and colonial curriculum and teaching methods at universities. This is in line with Letsekha's argument that the higher education system requires a 'fundamental overhaul of the whole epistemological model underlying the current educational system' (2013:9). However, this will not be easy, as there are many powerful individuals and interest groups who will do all it takes to contest, resist and water down the change in order to maintain the status quo. Students, progressive academics, university staff and the concerned public must maintain the non-violent, intellectual, evidence-based, emotional and popular struggle until epistemic violence and Eurocentrism are dismantled.

\section{Colonialism, apartheid and higher education in South Africa}

This section reflects on higher education during colonial and apartheid times. Eurocentrism, racism, segregation and epistemic violence at South African universities were not products of the apartheid state. Rather, these problems began with the establishment of the universities by the British colonialists and further evolved after 1948 (Sehoole 2006:4). Imperial and colonial rule included both direct and indirect socio-economic and political control, dominance and exploitation of resource-rich parts of the world by the European powers in the form of settler or extractive colonies
(Mamdani 1996:17). Apart from exploitation, one of the drivers of colonial and imperial occupation was the belief by the colonialists that they were superior human beings on a mission to save and 'civilise' the 'uncivilised' peoples in the colonies (Mudimbe 1985:181). Bain (2003:64-65) writes that the colonisers believed they had a 'paternal duty that obliged self-proclaimed trustees of civilisation to seek the good of the disadvantaged'. They saw themselves as providers of supervision and guidance to the 'weak' and 'childlike' peoples in the colonies (Mamdani 1996:4; McEwan 2009:220).

Kelley (2000:27) writes that 'colonial domination required a whole way of thinking, a discourse in which everything that is advanced, good and civilised is defined and measured in European terms'. In this process, colonial education played an instrumental role, promoting and imposing the Eurocentric 'ways' and worldviews while subjugating everything else. Thus, one of the most destructive effects of colonialism was the subjugation of local knowledge and promotion of the Western knowledge as the universal knowledge. European scholars have worked hard for centuries to erase the historical, intellectual and cultural contributions of Africa and other parts of the 'non-Western' world to our common humanity. They have done this as part of the white supremacist project. In the process, they have reduced the 'other' in their texts to 'little more than beasts of burden or brutish heathens' (2000: 22), instilling in the colonised masses an inferiority complex (Césaire 2000:43; Mudimbe 1985:175). As Said (1994:8) points out, the Western European literature has for centuries portrayed the non-Western world and peoples as 'inferior' and 'subordinate'; this helped 'normalise' racism among the colonialists and developed a notion that 'Europe should rule, non-Europeans ruled' (1994:120).

In South Africa, the colonial universities ${ }^{2}$ were set up by 'settler elites who saw them as both symbols and disseminators of European civilisation in the colonies' (Pietsch 2013). The role of universities - which were part and parcel of the colonial project - was to promote white supremacy and develop the white youth to maintain and further expand colonial society (Pietsch 2013; Ramoupi 2011:5). Colonial universities 'were unapologetically Eurocentric, patterned on the metropolitan universities from which they drew much of their faculty and curricula' (Zeleza 2009:114). Pietsch (2013) further explains how:

Presuming the universality and superiority of 'Western' culture, these 'settler' universities established themselves as the local representatives of 'universal' knowledge, proudly proclaiming this position in the neo-gothic buildings they erected and the Latin mottos they adopted.

After the apartheid system was established in 1948, the epistemic violence and racism at universities were taken to another level. During apartheid, higher education was 'designed to entrench the power and privilege of the ruling white minority' (Bunting 2004:52). The 'conception of race

2.A number of colonial universities were established as bilingual institutions (both English and Afrikaans). This started to change in 1918, when some institutions English and Afrikaans). This started to change in 1918, when some institutions
were transformed into Afrikaans-medium universities due to the rise of Afrikaner nationalism and the demand for Afrikaans-only higher education (Du Plessis 2006:97). 
and the politics of race ... shaped the higher education policy'. This included designation of institutions for the exclusive use of particular racial groups (2004:35-36). Bunting (2004:40) writes that the councils and administrators at the historically white Afrikaans-medium universities gave full support to the apartheid regime and the white supremacy project. He adds that these 'instrumentalist institutions' ${ }^{3}$ were governed in a top-down and authoritarian manner.

The historically white English-medium universities considered themselves as 'liberal' institutions that had 'highly ambiguous relationships with the government during the apartheid years'. They received funding from the government but argued that they were not the 'servants of the state'. These institutions were governed in a fashion that was a 'mix of the collegial and the authoritarian' (2004:42-43). Although the English-medium universities saw themselves as the opponents of apartheid and agents for change, in reality they were islands of white privilege that benefited from apartheid's policies even if not openly supporting the government. Gibbon and Kabaki (2004:123) indicate that the entire higher education system 'served to construct and maintain the social, political and economic features of the apartheid order'. One of the ways it did this was by contributing 'to the systematic under-qualification of the majority black population'. While the Afrikaansmedium universities worked closely with the government on this, the English-medium universities also played a role in maintaining the segregation and oppression. Mamdani (1998:64) argues that the South African academy, even when it was opposed to apartheid politically, was deeply affected by it epistemologically'. Sehoole (2006:5) adds that during apartheid, most of the English- and Afrikaansspeaking academia 'shared whiteness - a belief in white hegemony in South Africa'.

Historically black universities (including the universities in the homelands) were established and/or maintained to train black people to serve first the colony ${ }^{4}$ and then the apartheid state. This included developing professionals such as teachers, homeland administrators and bureaucrats. This way the black universities 'played a role in the maintenance of the overall apartheid socio-political agenda' (Bunting 2004:45). While the white universities promoted Eurocentrism and white supremacy, 'black universities were irredeemably condemned to the mediocrity of Bantu education' (Zeleza 2009:115), training students to become the servants of the white 'masters' (Ramoupi 2014:270). As in the case of the white institutions, governance systems at black universities 'tended to be highly authoritarian' and dominated by white Afrikaners who had graduated from Afrikaans-medium universities. Furthermore, the intellectual and academic agendas of the black universities 'were set by their apartheid origins' and driven mainly by white academics (Bunting 2004:45).

3. Instrumentalist institutions are universities whose main aim is 'dissemination and generation of knowledge for a purpose defined or determined by a socio-polit gener (Bunting 2004:40). : $4: 40)$

4.This includes missionary education, which was part of the colonial project (Mudimbe 1985)

\section{Eurocentrism and epistemic violence in 'new' South Africa}

Two decades after the end of apartheid, the curriculum ${ }^{5}$ at South African universities is still largely Eurocentric, rooted in the colonial and apartheid dispossession, looting and humiliation of Africa and its people. The Eurocentric curriculum focuses on:

The idea of Europe, as a metaphor, and turns all others into bit players or loiterers without intent on the stage of world history, either too lazy to do anything ourselves or always late, and running behind to catch up with Western modernity. (Pillay 2015)

After 1994, epistemological transformation was supposed to entail a 'reorientation away from the [colonial and] apartheid knowledge system, in which curriculum was used as a tool of exclusion, to a democratic curriculum that is inclusive of all human thought' (Department of Education 2008:89). However, universities have failed to do much, if anything, to change the curriculum since the demise of apartheid. As the Department of Education concluded in 2008 (and there has been hardly any change since then), the transformation efforts have not 'translated into any significant shifts in the structure and content of the curriculum' (2008:90). The curriculum 'is inextricably intertwined with the institutional culture and, given that the latter remains white ${ }^{6}$ and Eurocentric at the historically white institutions, the institutional environment is not conducive to curriculum reform' (2008:91).

Thus, what we have in most fields of study (and particularly in the humanities and social sciences) is Eurocentric indoctrination, which marginalises Africa and is often full of patronising views and stereotypes about the continent: 'European and white values are [still] perceived as the standards on which the country's education system is based and rooted' (Ramoupi 2011:5). Eurocentrism, which dominates the curriculum, 'seeks to universalize the West and provincialize the rest' (Zeleza 2009:133). Such education does not critically interrogate the 'outcomes of a history of patriarchy, slavery, imperialism, colonialism, white supremacy and capitalism' (Molefe 2016:32). Quite contrary, the one-sided and subjective 'epistemological truth' promoted by those who are trying to maintain the status quo is a 'reproduction of epistemological blindness that silences other knowledges and ways of creating knowledge' (Motta 2013:97). Pillay (2015) argues that this kind of education ensures that the students end up: 'ignorant of most of the world [and particularly Africa] and arrogant about our ignorance' (original emphasis). He adds that this is nothing but 'epistemic violence' imposed on the students by the South African academia.

5.'Higher education curriculum' refers to 'what knowledge is included or excluded in university teaching and learning programmes' (Letsekha 2013:8).

6.'Racism and patriarchy' were 'key features of colonialism and apartheid'. As such, they profoundly shaped the composition of academic staff at universities. In 1994, $83 \%$ of academics in South Africa were white, whereas $68 \%$ were male. In 2012, the $83 \%$ of academics in South Africa were white, whereas $68 \%$ were male. In 2012, the
whites still made up $53 \%$ and males $55 \%$ of full-time permanent academic staff (HESA 2014:8). 
Spivak (1994) defines 'epistemic violence' as the Eurocentric and Western domination and subjugation of the [former] colonial subjects and misconception of their understanding and perception of the world. This is a result of 'violence of imperialistic epistemic, social and disciplinary inscription' (1994:80). Epistemic violence erases the history of the subaltern $^{7}$ (1994:83) and also convinces them that they do not have anything to offer to the 'modern' world; their only option is to blindly follow the 'enlightened' colonisers, learn from them, adopt their worldviews and fit into the periphery of their world as second-class citizens.

Epistemic violence persists in post-apartheid South Africa, where the higher education system, rooted in colonial and apartheid exploitation and racism, has obliterated nearly all the linkages that black students may have with the prescribed texts, propagated narratives, debates and learning on the one side and their history, lived experiences and dreams on the other side. In the old colonial fashion, they are the 'other' in their country of birth, not recognised and valued unless they conform. Through education, they are expected to learn to 'speak well' and gain skills and Eurocentric knowledge that will allow them to enter the marketplace but not allow them to fundamentally change the status quo in society and the economy.

\section{Africa in the current curriculum}

The colonial and apartheid curriculum in South Africa has promoted white supremacy and dominance, as well as stereotyping of Africa. The current higher education curriculum still largely reflects the colonial and apartheid worldviews (Ramoupi 2014:271) and is disconnected from African realities, including the lived experiences of the majority of black South Africans. Most universities still follow the hegemonic 'Eurocentric epistemic canon' that 'attributes truth only to the Western way of knowledge production' (Mbembe 2016:32). Such a curriculum does not develop students' critical and analytical skills to understand and move the African continent forward. Gqola (2008:222) asserts that since 1994, South African universities have not done nearly enough to open their students' horizons about Africa. This has 'contributed to the ignorance of the continent we are part of and inadvertently allowed the faceless African man and woman to remain throw-away people'.

Jansen (1998:109) writes that the failure to increase the number of black academics and decolonise the curriculum have 'left unchallenged the Achilles heel of [previously] white institutions: the kind of knowledge (and therefore authority) which is passed on to African students as unquestionable truth and inscrutable value'. The curriculum continues to 'reinforce the prejudice' that there is not much we can learn from Africa, developing countries and the 'third world' and that 'universal' knowledge rests in the Western world (Pillay 2015). When Africa appears in the curriculum, it is not more than a 'version

7.At universities in the colonies, 'native' history was devalued while the history of the colonial power was promoted and celebrated (Said 1994:270). The negative effects of this would remain for many decades after independence. of Bantu education ... students are being taught a curriculum which presumes that Africa begins at the Limpopo, and that this Africa has no intelligentsia worth reading' (Mamdani 1998:74). ${ }^{8}$ Accordingly, most South African academics who teach about Africa rely primarily on Western interpretations of the continent. Knowledge about Africa produced by African academics is largely ignored.

Reliance on Western knowledge about Africa is an old colonial and imperial notion. As Mamdani (1998) points out:

the idea that natives can only be informants, and not intellectuals, is part of an old imperial tradition. It is part of the imperial conviction that natives cannot think for themselves; they need tutelage. (p. 71)

Reflecting on the Western knowledge about the African continent and its people, Mbembe (2001) notes the following:

Reduced to impatience and ignorance, carried away by verbal delirium, slogans, and linguistic inadequacy - with some analysts, only reading French, others only English, and few speaking local languages - the literature lapses into repetition and plagiarism; dogmatic assertions, cavalier interpretations, and shallow rehashes become the order of the day. (pp. 8-9)

Thus, the writings by Western academics and researchers, who often claim that Africa is nothing but misery, corruption, 'darkness' and irrationality ${ }^{9}$ (Mbembe 2001) and cannot survive without a 'kind, white foreigner' (Ngozi Adiche 2009), are frequently used as reference points to teach about Africa at South African universities. When this kind of knowledge is used to teach about the continent, we cannot expect anything but distance, alienation and misunderstanding of the causes of the past and current problems and lack of vision for the future.

\section{Fundamental change}

Writing about decolonisation of higher education in Kenya at the end of 1960s, Garuba (2015) stresses that a 'fundamental question of place, perspective and orientation needed to be addressed in any reconceptualisation of the curriculum' and that Kenya, East Africa and Africa needed to be placed at the centre of teaching, learning and research at Kenyan universities. A more detailed account of the quest for transformation of the curriculum in post-colonial Kenya is in Ngugi wa Thiong'o's Decolonising the Mind: The Politics of Language in African Literature (1981). Ngugi writes that the transformation required looking at the curriculum in terms of the 'relevance to our situation ... [and the] contribution towards understanding ourselves'. Ultimately, the goal was to establish the 'centrality of Africa' in the curriculum (1981:94). Similar decolonisation processes took place in many African countries after independence, where universities went through 'vigorous efforts ... to decolonise the disciplines, to strip them of their Eurocentric cognitive

8.The above quotes from Jansen and Mamdani, both from 1998, still to a great extent describe the South African higher education system.

9.The African continent 'stands out as the supreme receptacle of the West's obsession with, and circular discourse about, the facts of "absence," "lack" and "non-being," of identity and difference, of negativeness - in short, of nothingness' (Mbembe 2001:4). 
and civilisational conceits' (Zeleza 2009:112). Local academics used 'reflexivity and critical analysis' to establish themselves and their societies 'as "subjects" of their own destiny' as well as to reinvent their past and envision their future (Mudimbe 1985:206).

When we talk about and engage in reconceptualisation and decolonisation of the curriculum in South Africa, we need to consider the two approaches discussed by Garuba. The first approach is to 'add new items to an existing curriculum'. The second approach is to 'rethink how the object of study itself is constituted' and then reconstruct it and bring about fundamental change (Garuba 2015). The first approach is promoted at South African universities by those who want to maintain the status quo. This group wants to keep Eurocentric worldviews in the curriculum but add to it 'bits and pieces of Africa' and 'the other' previously colonised places and peoples. This approach allows for ticking of the boxes and saying 'we are busy reforming and transforming'. Pillay (2015) writes that this approach would lead to settling 'for a supplemental concept of history, where we now add African Studies onto the existing curriculum with the danger of once more ghettoizing it from the other mainstream disciplines'. The end result would be the continued dominance of Eurocentric worldviews.

The fundamental change can happen only if universities embark on the second approach described by Garuba above. For Césaire (2000:89), 'decolonisation is about the consciousness and rejection of values, norms, customs and worldviews imposed by the [former] colonisers'. Ngugi (1981:87) argues that decolonisation of the curriculum is about Africans seeing themselves 'clearly in relationship with ourselves and other selves in the universe'. He calls this 'a quest for relevance'. The change at universities must entail 'decolonising, deracialising, demasculanising and degendering' the institutions as well as 'engaging with ontological and epistemological issues in all their complexity, including their implications for research, methodology, scholarship, learning and teaching, curriculum and pedagogy' (HESA 2014:7). Kaya and Seleti (2013:33) argue that decolonised academia must reject the 'utilisation of dominant Western worldview of knowing and knowledge production as the only way of knowing' (emphasis added). It is important to note that decolonisation does not require removing white men and women, both foreign and local, from the curriculum. However, they cannot be seen as the all-knowing and all-important canon upon which the human knowledge rests and through which white and Western domination is maintained. As Mbembe (2016:35) points out, decolonisation 'is not about closing the door to European or other traditions. It is about defining clearly what the centre is'. Ngugi (1981:93) adds that Europe cannot remain at the centre of the universe at African universities; Africa must be at the centre.

The South African higher education system needs what Zeleza (2009:127) calls the 'deconstructionist' movement to 'dismantle the Eurocentric epistemic hegemonies that have dominated the study of Africa'. The curriculum must be transformed 'in the context of post-apartheid South Africa and its location in Africa and the world' (Department of Education 2008:21). Jansen (1998:110-111) further emphasises that:

Content matters, and it matters a great deal when a Europeancentred curriculum continues to dominate and define what counts as worthwhile knowledge and legitimate authority in South African texts and teaching; it matters very much in the context of the inherited curriculum, informed by apartheid and colonialism, in which only the more readily observable, offensive racism has been skimmed off the top.

Decolonisation of the curriculum also entails 'linking colonial and discriminatory legacies to the here and now' (Langdon 2013:394), which in South Africa is an ever-present painful reality for many. Eliminating past and current injustices should not be limited to 'material inequality, poverty and the more familiar tropes of violence. We should also aim to reduce injustices in the production of knowledge' (McKaiser 2016).

Universities must completely rethink, reframe and reconstruct the curriculum and bring South Africa, Southern Africa and Africa to the centre ${ }^{10}$ of teaching, learning and research. This in no way means that decolonisation will lead to localisation, isolation or only Africanisation of the curriculum. Africa will not be the only 'focus of the curriculum in the ethnocentric-particularist manner of [the current] Eurocentric approaches'. Decolonised curriculum will not neglect other knowledge systems and global context (Department of Education 2008:92). Universities still have to develop globally competent graduates capable of functioning in the complex and connected world. In the decades to come, South Africa aims to play an important role in Africa, within the BRICS ${ }^{11}$ and in the world - from economics, development, international relations, politics and conflict management to peace-building and security. To do this successfully, the country's universities will have to develop graduates who possess knowledge about the world and all its complexity. ${ }^{12}$ However, the education must be free from Western epistemological domination, Eurocentrism, epistemic violence and world views that were designed to degrade, exploit and subjugate people in Africa ${ }^{13}$ and other parts of the formerly colonised world. In addition, South African academia must be critical of the 'global knowledge' and not accept anything from the global North as the norm. Finally, the call for decolonisation of the curriculum 'is neither an

10.South African universities currently have miniscule and often superficial institutional partnerships on the African continent. The majority of their functional partnerships are in the global North (Kaya \& Seleti 2013:32; Sehoole 2006:11). If Africa is to be the central focus of the research and curriculum, increased collaboration between universities and academics from South Africa and the rest of the continent is of utmost importance.

11.The BRICS is a geopolitical and economic grouping comprising Brazil, Russia, India, China and South Africa.

12.This requires reading, critiquing, analysing, comparing and contrasting diverse academic and literary works and points of view and not only (or mainly) the Western and Eurocentric ones.

13.De Wit (2012) argues that higher education in Africa may need to first go through a 'process of de-internationalisation, to liberate itself from [colonial and] external influences, before it can develop its own position in the global knowledge society'. 
advocacy to be anti-West, nor is it discouragement to learn from the West' and the rest of the world. Rather, it is a call to make higher education 'relevant to the material, historical and social realities of the communities in which universities operate' (Letsekha 2013:14).

\section{Fit to teach at a decolonised university?}

Macedo (1993:189) writes about the 'social construction of not seeing' that has been prevalent among white South Africans for decades. In the current context, this refers to the 'wilful blindness' (1993:189) by whites but also many rich and middle-class black, coloured and Indian South Africans to the everyday realities and struggles of the poor and marginalised black majority in the country. This is also prevalent at universities, where the leaders, managers, staff members, academics and well-off students often turn a blind eye to the painful lived experiences that many black students and workers go through on a daily basis. How else to explain the lack of awareness of the blatant exploitation of the outsourced cleaning, support and security staff at universities? For years, the people who were employed to clean and take care of the campuses and ensure the safety and security of the university management, academics, staff and students have been exploited by private companies selected and paid by the universities to provide these services. Hardly anyone took notice, asked about or attempted to stop this exploitation. If it wasn't for the \#FeesMustFall movement, which incorporated the struggle of the outsourced workers into their own struggle, universities would not have done anything on their own to stop the ill treatment of the poorest of the poor.

This leads to an important question: can those who don't care about the poor that protect them and clean up after them at the workplace educate students to become good, ethical and critical citizens and change agents? If they don't care about the injustice and inequality that surrounds them, how will they care and do something about the inequality and injustice in the country, on the continent and in the world? Mkhize (2015) adds an equally important question:

Can our universities be trusted to demonstrate contextually relevant, socially intelligent responses to pressing social questions when so many in their ranks seem to be struggling with basic sociological concepts such as 'race' and what defines 'racism'?

Decolonisation of higher education is 'about justice that addresses the epistemic violence of colonial knowledge and colonial thought' (Pillay 2015). South Africa needs a higher education system to develop graduates and intellectuals who can address the epistemic violence of the past and present and who will go on to rewrite the 'histories and humanity [of both South Africa and Africa] so cruelly seized and denied by Europe' (Zeleza 2009:116) throughout centuries. However, where to find leaders, administrators and academics capable of addressing deep-rooted epistemic violence? Where to find academics who possess knowledge and passion about the African continent? When it comes to knowledge about Africa, most of South Africa's white academics are intellectually and academically out of touch. 'Because of their racially privileged positions' in the past, they 'had risen up the ranks without having to engage three decades of rigorous post-independence African scholarship' (Mkhize 2015). Many still assume that the Western knowledge systems 'constitute the only basis for higher forms of thinking' (Department of Education 2008:91). Thus, the involvement of white academics in the decolonisation project 'requires self-reflexivity' (Langdon 2013:385), recognition of privilege, personal change and growth as well as unlearning of the old knowledge designed to subjugate and exploit 'the other'. The epistemological transformation also depends on the significant increase of black, coloured and Indian academics at universities (HESA 2014:8). However, even if black academics and administrators replace whites, this does not necessarily guarantee fundamental change. Ramoupi (2014:271) argues that the leadership change at many universities - from white to black, coloured or Indian vice-chancellors, their deputies or deans - didn't lead to 'substantial paradigm shifts meant to bring about meaningful decolonisation of the curriculum and content'. Furthermore, as Maserumule (2015) points out:

The continent's professoriate is schooled largely in the white tradition. This imprinted the culture of whiteness in its making, which is not surprising. Western education in Africa as we know it is designed to proselytise blacks. African academics may be reluctant to repudiate their very make-up.

Maserumule (2015) adds that fundamental change requires academics and administrators 'with a decoloniality posture'. The challenge in South Africa is that academics and administrators with a decoloniality posture are a minority at universities. Many come from the old system that worked hard to maintain apartheid and white domination; some have enjoyed the white privilege while claiming to be against apartheid or, in the case of many black academics and administrators, were indoctrinated during apartheid. Thus, the struggle to decolonise higher education will be a long one, possibly requiring new generations of academics and administrators - who were not part of the old system and who are representative of the country's demographics - to reach senior positions at universities.

\section{Conclusion}

'Direct colonial rule may have disappeared; but colonialism, in its many disguises as cultural, economic, political and knowledge-based oppression, lives on' (Sardar 2008:xix). If one adds the term 'apartheid' after 'colonialism' in the above quote, we get a true picture of post-apartheid South Africa, where colonial and apartheid marginalisation, racism and exploitation live on in many spheres of life and work, including higher education. If universities and academics want to genuinely contribute to socio-economic transformation in the country and on the African continent, they have to profoundly change what they teach and how they do it. 
The current Eurocentric curriculum - coupled with epistemic violence - does not contribute to a much-needed reimagining of the past and shaping of the present and future on the African continent. This can only be achieved through a curriculum that 'reconstructs' Africa from the historical, civilisational, political economy and political standpoint perspectives (Mamdani 1998). However, this will not happen until the Eurocentric institutional cultures and staff demographics at universities fundamentally change (Department of Education 2008).

The opposition to change is entrenched within the university structures and will not easily allow the breaking down of the grip on power, privilege, influence and decision-making. This group will do everything in its power to contest, resist and water down the change, ${ }^{14}$ as 'any intellectual challenges to the orthodoxy that underpins' any field of study will 'provoke the ire of those who benefit most from the status quo' (Lagardien 2014). Thus, the debates about decolonisation make many at universities uncomfortable. This is important and necessary, as change will not happen if people are comfortable with the status quo. Decolonisation requires a large mass of people demanding change on the campuses and in society. They will have to confront the 'official orthodoxy' (Mudimbe 1985:209) and 'consciously disrupt the status quo' (Nwadeyi 2016). Social and structural change seldom happens anywhere in the world without activism, advocacy, dissent, disruption and protest. The powerful and influential don't simply give in because it is the right thing to do; they only act when they are compelled to do so by social movements and masses.

Progressive academics and lecturers must take the lead and not wait until the institutional cultures and environments transform. They need to decolonise their own curriculum and democratise the learning space in which they operate. In particular, they have an opportunity to involve students in the process of transformation of the curriculum, teaching and learning. Academics and lecturers can do this by creating an 'anti-hierarchical' space in their classrooms where everyone learns, engages, debates and critically reflects together (Rouhani 2012:1731). Freire (1970:69) sees this as an educational space where lecturers and students jointly work on 'unveiling the reality', understanding it critically and recreating the knowledge in the process. This is in line with Motta's (2013:88) notion that 'the process of constructing knowledge needs to be reclaimed and remade as a critical act of opening possibility through developing pedagogies (as method and content) with students'.

'Radical departures from the status quo are never easy. They are always simultaneously symbolic and visceral. But they open up new possibilities for questioning what was once unquestioned and unquestionable' (Msimang 2015). This is exactly what the South African higher education system needs today - a radical departure from the status quo and questioning the colonial and apartheid knowledge systems that until now have not been questioned sufficiently, if at all. The movement to transform and decolonise higher education a coalition of students, progressive academics, university staff and concerned public - must find ways to hold the institutions accountable and maintain the non-violent, intellectual, evidence-based, emotional and popular struggle until Eurocentrism and epistemic violence at universities are dismantled.

\section{Acknowledgements Competing interests}

The author declares that he has no financial or personal relationships that may have inappropriately influenced him in writing this article.

\section{References}

Bain, W., 2003, 'The political theory of trusteeship and the twilight of international equality', International Relations 17(1), 59-77. http://dx.doi.org/10.1177/0047 1178030171004

Bunting, I., 2004, 'The higher education landscape under apartheid', in N. Cloete, P. Maassen, R. Fehnel, T. Moja, H. Perold. \& T. Gibbon (eds.), Transformation in higher education: Global pressures and local realities in South Africa, pp. 35-52, Kluwer Academic Publishers, Dordrecht.

Césaire, A., 2000, Discourse on colonialism, Monthly Review Press, New York.

De Wit, H., 2012, 'Africa must lead innovation in higher education internationalisation', University World News, 16 September, Issue No. 239, viewed 18 June 2016, from $\mathrm{http}: / /$ www.universityworldnews.com/article.php?story=20120912160836275

Department of Education, 2008, Report of the ministerial committee on transformation and social cohesion and the elimination of discrimination in public higher education institutions, Final Report, Department of Education, Pretoria.

Du Plessis, T., 2006, 'From monolingual to bilingual higher education: The repositioning of historically Afrikaans-medium universities in South Africa', Language Policy 5(1), 87-113. http://dx.doi.org/10.1007/s10993-005-5627-5

Freire, P., 1970, Pedagogy of the oppressed, 30th edn., The Continuum International Publishing Group Inc., New York.

Garuba, H., 2015, 'What is an African curriculum?', Mail \& Guardian, 17 April, viewed 15 June 2016, from http://mg.co.za/article/2015-04-17-what-is-an-africancurriculum/

Gibbon, T. \& Kabaki, J., 2004, 'Staff', in N. Cloete, P. Maassen, R. Fehnel, T. Moja, H. Perold. \& T. Gibbon (eds.), Transformation in higher education: Global pressures and local realities in South Africa, pp. 123-152, Kluwer Academic Publishers, Dordrecht.

Gqola, P.D., 2008, 'Brutal inheritances: Echoes, negrophobia and masculinist violence', in S. Hassim, T. Kupe. \& E. Worby (eds.), Go home or die here: Violence, xenophobia and the reinvention of difference in South Africa, pp. 209-223, Wits University Press, Johannesburg.

Higher Education South Africa (HESA), 2014, 'South African higher education in the 20th year of democracy: Context, achievements and key challenges', presentation to the Portfolio Committee on Higher Education and Training, Cape Town, 5 March.

Jacobs, S., 2016, 'Student protests and post-apartheid South Africa's negative moment', Africa is a Country, 18 May, viewed 2 July 2016, from http:// africasacountry.com/2016/05/student-protests-and-postapartheid-south-africasnegative-moment

Jansen, J.D., 1998, 'But our natives are different! Race, knowledge and power in the academy', Social Dynamics 24(2), 106-116. http://dx.doi.org/10.1080/025339 academy', Social
59808458653

Kaya, H.O. \& Seleti, Y.N., 2013, 'African indigenous knowledge systems and relevance of higher education in South Africa', The International Education Journal: Comparative Perspectives 12(1), 30-44.

Kelley, R.D.G., 2000, 'A poetics of anticolonialism', in A. Césaire (ed.), Discourse on colonialism, pp. 7-28, Monthly Review Press, New York.

Lagardien, I., 2014, 'Help students challenge economics', Mail \& Guardian, 7 March, viewed 19 June 2016, from http://mg.co.za/article/2014-03-07-help-studentschallenge-economics

Langdon, J., 2013, 'Decolonising development studies: Reflections on critical pedagogies in action', Canadian Journal of Development Studies 34(3), 384-399. $\mathrm{http}: / / \mathrm{dx}$.doi.org/10.1080/02255189.2013.825205

Letsekha, T., 2013, 'Revisiting the debate on the Africanisation of higher education: An appeal for a conceptual shift', The Independent Journal of Teaching and Learning 8, 5-18.

Macedo, D.P., 1993, 'Literacy for stupidification: The pedagogy of big lies', Harvard Educational Review 63(2), 183-206. http://dx.doi.org/10.17763/haer.63.2. c626327827177714 
Mamdani, M., 1996, Citizen and subject: Contemporary Africa and the legacy of late colonialism, Princeton University Press, Princeton, NJ.

Mamdani, M., 1998, 'Is African studies to be turned into a new home for Bantu education at UCT?', Social Dynamics 24(2), 63-75. http://dx.doi.org/10.1080/02 533959808458649

Maserumule, M.H., 2015, 'Why Africa's professors are afraid of colonial education being dismantled', The Conversation, 25 November, viewed 30 November 2015, from https://theconversation.com/why-africas-professors-are-afraid-of-colonialeducation-being-dismantled-50930

Mbembe, A., 2001, On the postcolony, University of California Press, Berkeley, CA.

Mbembe, A., 2016, 'Decolonising the university: New directions', Arts \& Humanities in Higher Education 15(1), 29-45. http://dx.doi.org/10.1177/1474022215618513

McEwan, C., 2009, Postcolonialism and development, Routledge, New York.

McKaiser, E., 2016, 'Epistemic injustices: The dark side of academic freedom', 2016 DCS Oosthuizen Academic Freedom Memorial Lecture, Rhodes University, Grahamstown, 30 May, viewed 17 June 2016, from http://www.iol.co.za/news/ epistemic-injustices-the-dark-side-of-academic-freedom-2029747

Mkhize, N., 2015, 'Anger over Rhodes vindicates Mamdani', Business Day, 7 April, viewed 18 June 2016, from http://www.bdlive.co.za/opinion/columnists/2015/ 04/07/anger-over-rhodes-vindicates-mamdani

Molefe, T.O., 2016, 'Oppression must fall: South Africa's revolution in theory', World Policy Journal 33(1), 30-37. http://dx.doi.org/10.1215/07402775-3545858

Motta, S.C., 2013, 'Teaching global and social justice as transgressive spaces of possibility', Antipode 45(1), 80-100. http://dx.doi.org/10.1111/j.1467-8330. 2012.00995.x

Msimang, S., 2015, 'The old is dying and the young ones have just been born', Africa is a Country, 15 May, viewed 2 July 2016, from http://africasacountry. com/2015/05/the-old-is-dying-and-the-young-ones-have-just-been-born/

Mudimbe, V.Y., 1985, 'African gnosis philosophy and the order of knowledge: An introduction', African Studies Review 28(2/3), 149-233. http://dx.doi.org/ $10.2307 / 524605$

Ngozi Adiche, C., 2009, The danger of a single story, TED Global, video recording viewed 16 June 2016, from http://www.ted.com/talks/chimamanda adichie the_danger_of_a_single_story
Ngugi, W.T.O., 1981, Decolonising the mind: The politics of language in African literature, East African Educational Publishers Ltd., Nairobi.

Nwadeyi, L., 2016, 'We all have a responsibility to disrupt the status quo', Mail \& Guardian, viewed 30 June 2016, from http://mg.co.za/article/2016-06-29-we-allhave-agency-and-we-must-use-it-to-disrupt-the-status-quo

Pietsch, T., 2013, 'Empire and higher education internationalisation', University World News, 20 July, Issue No: 282, viewed 19 June 2016, from http://www. universityworldnews.com/article.php?story=20130718115637589

Pillay, S., 2015, 'Decolonising the university', Africa is a Country, viewed 16 June 2016, from http://africasacountry.com/2015/06/decolonizing-the-university/

Ramoupi, N.L.L., 2011, African-centred education and African languages: Content and curriculum in post-apartheid education and training in South Africa, Briefing No. 56, Africa Institute of South Africa, Tshwane.

Ramoupi, N.L.L., 2014, 'African research and scholarship: 20 years of lost opportunities to transform higher education in South Africa', Ufahamu: A Journal of African Studies 38(1), 269-286.

Rouhani, F., 2012, 'Practice what you teach: Facilitating anarchism in and out of the classroom', Antipode 44(5), 1726-1741.

Said, E., 1994, Culture and imperialism, Vintage, London.

Sardar, Z., 2008, 'Foreword to the 2008 edition. I think it would be good if certain things were said: Fanon and the epidemiology of oppression', in F. Fanon 1967 Black skins, white masks, 2008 edn., pp. vi-xx, Pluto Books, London.

Sehoole, C., 2006, 'Internationalisation of higher education in South Africa: A historical review', Perspectives in Education 24(4), 1-13.

Shay, S., 2016, 'Decolonising the curriculum: It's time for a strategy', The Conversation 13 June, viewed 15 July 2016, from https://theconversation.com/decolonisingthe-curriculum-its-time-for-a-strategy-60598

Spivak, G.C., 1994, 'Can the subaltern speak?', in P. Williams \& L. Chrisman (eds.) Colonial discourse and post-colonial theory: A reader, pp. 66-111, Harvester/ Wheatsheaf, New York.

Zeleza, P.T., 2009, 'African studies and universities since independence: The challenges of epistemic and institutional decolonization', Transition (101), 110-135. http:// dx.doi.org/10.2979/trs.2009.-.101.110 